УДК 811.161.2'272

DOI https://doi.org/10.24919/2308-4863.3/30.212373

Людмила САЛІОНОВИЧ, orcid.org/0000-0001-9005-9273 кандидат філологічних наук,

доиент кафедри міжкультурної комунікації та іноземної мови Національного технічного університету «Харківський політехнічний інститут» (Харків, Украӥна) l.salionovych@gmail.com

Тетяна НЕТЕЦЬКА, orcid.org/0000-0001-5298-0563 доиент кафедри міжкультурної комунікаиії та іноземної мови Національного технічного університету «Харківський політехнічний інститут» (Харків, Україна) tannett29@gmail.com

\title{
СТАТУС УКРАЇНСЬКОЇ МОВИ ЯК ДЕРЖАВНОЇ В ДОБУ НЕЗАЛЕЖНОСТІ: СОЦІОКУЛЬТУРНИЙ АСПЕКТ
}

Статтю присвячено висвітленню проблем, пов 'язаних із впровадженням державної мовної політики в Україні взагалі й забезпеченням конституиійних прав національних меншин щзодо мовного питання $і$ надання їм можливостей для реалізації циих прав зокрема.

Метою статті є дослідження й аналіз законодавчо-правових, етнополітичних, сочіокультурних $і$ демографічних чинників, щзо впливають як на формування мовної політики в Украйні взагалі, так і на проблеми мовної рівності зокрема.

Проаналізовано правове поле зазначеної проблеми. До аналізу було залучено Конституцію України, закони «Про засади державної мовної політики», «Про національні мениини України», «Про освіту», «Про забезпечення функціонування украӥнської мови як державної», Рішення Конституційного Суду з питання конституційності зазначених вище законів, у результаті чого було зроблено висновок, щзо законодавчо-правова база в Украӥні иілком відповідає міжннародним правовим стандартам. Основна проблема полягає у підвищенні статусу української мови як державної, $і$ ияя проблема залишається невирішеною протягом усієї доби незалежсності. Далі було розглянуто етнічний склад населення Украӥни і з 'ясовано, щчо приблизно 23\% населення Украӥни становлять начіональні меншини. Розглянуто, які громадські організаиії діють на території України, зокрема у місті Харкові, їхню кількість та активність.

Хоча Закон «Про забезпечення функиіонування української мови як державної» певним чином обмежує можливості громадян щуодо використання мов національних меншин на державному рівні, він не обмежує права на вивчення рідної мови тієї чи іншої національності. Те, щчо єдиною державною (офіиійною) мовою в Україні є українська мова, є невіддільним елементом конституційного ладу Украӥни, як і будь-якої іншої унітарної держсави. Україні необхідна державна програма зі створення позитивного іміджу украӥнської мови серед населення, щчо сприятиме як дотриманню законодавчо-правової бази, так і нівелюванню проблем, пов 'язаних із мовним питанням.

Ключові слова: мовна політика, наџіональні меншини, громадські об'єднання, статус державної мови.

Liudmyla SALIONOVYCH, orcid.org/0000-0001-9005-9273

Candidate of Philological Sciences, Associate Professor at the Intercultural Communication and Foreign Language Department National Technical University "Kharkiv Polytechnic Institute" (Kharkiv, Ukraine) l.salionovych@gmail.com

Tetiana NETETSKA, orcid.org/0000-0001-5298-0563 Associate Professor at the Intercultural Communication and Foreign Language Department National Technical University "Kharkiv Polytechnic Institute" (Kharkiv,Ukraine) tannett29@gmail.com

\section{STATUS OF THE UKRAINIAN LANGUAGE AS THE STATE LANGUAGE IN THE INDEPENDENCE AGE: SOCIO-CULTURAL ASPECT}

The article deals with the problems related to the implementation of the state language policy in Ukraine, in particular, ensuring the constitutional rights of national minorities to the language issue and providing them with opportunities to exercise these rights. 
The purpose of the article is to study and analyze the legal, ethnopolitical and demographic factors that influence the formation of language policy in Ukraine in general and the problems of language equality in particular.

First, the legal field of this problem was analyzed. The Constitution of Ukraine, the laws "On the Principles of State Language Policy", "On National Minorities of Ukraine", "On Education", "On Ensuring the Functioning of the Ukrainian Language as the State Language", and the Constitutional Court's Decision on the constitutionality of the above Laws. It was concluded that the legal framework in Ukraine fully complies with international legislative standards. The main problem is to raise the status of the Ukrainian language as the state language. Next, the ethnic composition of the population of Ukraine was considered and it was found that approximately $23 \%$ of the population of Ukraine are national minorities. It is considered which public associations operate on the territory of Ukraine, in particular in the city of Kharkiv, their number and activity.

Although the Law "On Ensuring the Functioning of the Ukrainian Language as a State Language" in some way limits the possibilities of citizens to use the languages of national minorities at the state level, it does not restrict the right to learn the native language of a nationality. The fact, that the only state (official) language in Ukraine is the Ukrainian language, is an integral part of the constitutional order of Ukraine, as well as in any other unitary state. Ukraine needs a state program to create a positive image of the Ukrainian language among the population, which will contribute to both compliance with the legal framework and the leveling of problems related to the language issue.

Key words: language policy, national minorities, public associations, status of the state language.

Постановка проблеми. Сучасна мовна ситуація в Україні у всьому розмаїтті складників її факторів i постійному обговоренні залишається не досить вивченою, іiі дослідження вимагає залучення правничих, соціально-економічних, соціокультурних, етнополітичних і демографічних чинників. Аналіз зазначених чинників дасть змогу простежити зміну статусу української мови в країні за добу незалежності, визначити проблеми мовної державної політики й ситуації, пов'язаної з неукраїнськомовним населенням, що мешкає в Україні.

Аналіз досліджень. Мовним проблемам в українському суспільстві приділялася увага багатьох науковців. О. В. Яковлева досліджувала багатомовність українського суспільства як регулятивний фактор освіти і виховання (Яковлева, 2016); Н. П. Підбережник - проблеми, що виникають у сфері етнополітичних відносин в Україні (Підбережник, 2018); В. І. Андріяш - державну етнополітику України за умов глобалізації (Андріяш, 2013). Г. О. Юровська розглядала проблеми внутрішньо переміщених осіб (Юровська, 2017); тотожність понять державної та/або офіційної мови висвітлила у своїй роботі Г. В. Янковська (Янковська, 2014). Р. Д. Куртсеітов досліджував мовну толерантності та мовну політику Криму (Куртсеітов, 2012). П. П. Кононенко в численних працях аналізує розвиток та самопізнання українського народу (Кононенко, 2008). Водночас дослідженню проблем мовної рівності національних меншин приділялося не досить уваги.

Метою статті $є$ дослідження й аналіз законодавчо-правових, етнополітичних і демографічних чинників, що впливають як на формування мовної політики в Україні взагалі, так і на проблеми мовної рівності зокрема.

Виклад основного матеріалу. Вважаємо за доцільне почати аналіз зазначеної проблеми
3 юридичного підгрунтя, що регулює мовну політику в державі. Загальновідомо, що українська мова була визнана державною в 1989 р., що передувало підписанню Декларації про незалежність в 1991 р. Українська мова стала розглядатися як символ нової України, і проблема підвищення статусу української мови стала однією з центральних під час побудови незалежної держави.

У Конституції України, а саме у ст. 10 проголошено: «Державною мовою в Україні є українська мова. Держава забезпечує всебічний розвиток і функціонування української мови в усіх сферах суспільного життя на всій території України. В Україні гарантується вільний розвиток, використання і захист російської, інших мов національних меншин України. Держава сприяє вивченню мов міжнародного спілкування. Застосування мов в Україні гарантується Конституцією України та визначається законом» (Конституція України, 2019). Отже, законодавчо державна мова зрівнюється з мовами національних меншин.

Крім того, на зазначених у Конституції положеннях був прийнятий 3 липня 2012 р. Закон № 5029-VI «Про засади державної мовної політики» (Закон, 2012), що потрапив на розгляд Конституційного Суду через подання 57 депутатів, що наголошували як на порушенні процедури прийняття Закону, так і невідповідності його змісту Конституції, i, зрештою, був визнаний неконституційним за рішенням Суду від 28 лютого 2018 p. (Рішення, 2018). Отже, після шести років розгляду закон про мовну політику був скасований. Фактично рішення Суду обгрунтовано порушенням процедури прийняття закону, а не викладених у ньому положень.

Вартий уваги зокрема й той факт, що Закон № 2494-XII «Про національні меншини в Україні» (Закон, 1992) був прийнятий 25 червня 
1992 р., і останні зміни внесені до нього у 2012 р., у зв'язку зі скасованим нині Законом № 5029-VI, що наразі вже не має значення, подальші ж закони із зазначеним Законом № 2494-XII не узгоджувалися, хоча це вже питання здебільшого юридичного характеру.

Інший спалах громадських обговорень викликав прийнятий 5 вересня 2017 р. Закон № 2145VIII «Про освіту» (Закон, 2017), що також потрапив на розгляд Конституційного Суду за поданням 48 депутатів як такий, що не відповідає Конституції, але у даному випадку Судові знадобилося лише два роки для розгляду справи і визнання Закону таким, що відповідає Конституції України. Зокрема у рішенні, п. 3, наголошено, що «на рівні Закону передбачено засоби та механізми для реалізації особами, які належать до національних меншин та корінних народів України, права на вивчення мов відповідних національних меншин та корінних народів України разом із вивченням української мови як державної, оскільки вона є умовою свідомого об'єднання громадян у межах території України. У положеннях Закону, зокрема, вказується, що в Україні створюються рівні умови доступу до освіти; ніхто не може бути обмежений у праві на здобуття освіти; право на освіту гарантується, зокрема, незалежно від національності, мови спілкування (частина друга статті 3)» (Рішення, 2019). Отже, Закон «Про освіту» був визнаний Конституційним Судом як такий, що жодним чином не дискримінує права мовних меншин. Крім того, у 2018 р. у МОН України на виконання вищезгаданого Закону на постійній основі була створена Рада представників громадських об'єднань корінних народів, національних меншин України, що мала функціонувати як дорадчій орган при міністерстві, але офіційно на сайті $\mathrm{MOH}$ подана інформація лише про перше засідання, де обирався керівний склад Ради.

Згодом, 25 квітня 2019 р. Верховна Рада України прийняла Закон № 2704-VIII «Про забезпечення функціонування української мови як державної», метою якого $є$ захист української мови як державної і згідно з яким на державному рівні відбувається регулювання «функціонування і застосування української мови як державної у сферах суспільного життя» (Закон, 2019) на всій території України. Цей Закон також неодноразово підлягав критиці, але зрештою був прийнятий. Зазначимо, що перехідні положення мають набути чинності протягом чотирьох років 3 моменту прийняття, і це дає досить часу, скажімо, держслужбовцям для виконання всіх необхідних вимог з метою подальшого виконання обов'язків.
Однак незрозумілим залишається питання фінансування забезпечення прав національних меншин. У Законі йдеться лише про фінансування державою Національної комісії зі стандартів державної мови та Уповноваженого із захисту державної мови. Наразі не зовсім зрозуміло, яким коштом буде виконуватися, наприклад, це положення закону, ст. 21, п. 1: «Особам, які належать до корінних народів, національних меншин України, гарантується право на вивчення мови відповідних корінного народу чи національної меншини України в комунальних закладах загальної середньої освіти або через національні культурні товариства» (Закон, 2017). Забезпечувати право означає принаймні давати можливість, а дане право, як бачимо, не має конкретних механізмів його реалізації, і тому й надалі мовний закон викликатиме дискусії у суспільстві.

3 огляду на етнічний склад України зазначимо, що, на жаль, останні офіційні дані з цього питання були отримані й оприлюднені Держкомстатом України у результаті перепису населення 2001 р. Згідно 3 отримаю інформацією, на той час $77,8 \%$ населення складали українці, $17,3 \%$ росіяни, білоруси, молдовани, кримські татари, болгари, румуни, поляки, угорці, євреї, вірмени та ін. - менше 1\% (Про кількість і склад населення, 2001). Звичайно, у межах регіонів відсоток населення тих чи інших національних меншин міг варіюватися. За майже 20 років ситуація змінилася, населення з 48 млн на той час зменшилося за різними прогнозами до 42-37 млн, але за відсутності офіційних даних вважатимемо, що у відсотках національні меншини складають приблизно ту саму чисельність.

Далі розглянемо, які громадські об'єднання національних меншин наразі функціонують в Україні. Сайт Міністерства культури України (що функціонувало до 1 січня 2020 р.) містить певну інформацію щодо міжнародних і всеукраїнських заходів, які регулярно, деякі з 1980-х, відбуваються на всій території України - конкурсів, фестивалів, форумів та іншого, але всі зазначені заходи спрямовані на збереження й просування виключно української етнічної спадщини, жодної інформації щодо заходів, які проводять громадські об'єднання національних меншин, там не міститься (Мніністерство культури, 2020). Крім того, відсутня інформація про будь-які культурні центри, а власне на сторінці Департаменту у справах релігій та національностей міститься інформація лише про підрозділи та їх контактні дані. Після заснування Міністерства культури та інформаційної політики України (спочатку Міністерства 
культури, молоді та спорту України) даний департамент, можливо, припинив існування (інформація на сайті відсутня). Наразі тривають обговорення кандидатури на посаду Уповноваженого із захисту державної мови; також міністерство ініціювало у 2020 р. безліч заходів щодо обговорення майбутньої власної діяльності у різних містах України з метою оптимізації роботи, але, зрозуміло, впровадження карантинних заходів внесло певні корективи в ініціативи міністерства. Питання існування у міністерстві підрозділу, який займався б проблемами національних меншин, залишається відкритим (Міністерство культури та інформаційної політики, 2020), хоча за статутом саме вищезазначене міністерство вповноважене опікуватися захистом прав національних меншин, тому цілком можливо, що дане питання буде з часом врегульоване.

Однак слід наголосити, що в кожній міській та обласній адміністрації є департамент або інший підрозділ, що опікується проблемами національних меншин. Зазначені департаменти планують заходи невеликих масштабів та звітують перед держадміністрацією про їх проведення на регулярній основі, але, нажаль, зведених даних 3 приводу активності національних меншин на всій території України немає, і щоб уникнути необ'єктивності, зазначимо, що дане питання потребує окремого дослідження.

Більш-менш вичерпну інформацію щодо громадських об'єднань національних меншин можна отримати на офіційному порталі Київської міської державної адміністрації, де подано дані щодо самих дієвих громадських утворень (Офіційний портал Києва, 2020). Так, за даними сайту, в Україні діє близько 500 громадських організацій національних меншин.

Найактивнішою серед національних меншин $\epsilon$ єврейська громада, що заснувала 153 громадські організації різних напрямів по всій Україні. Зокрема, Сврейська Рада України, Асоціація єврейських організацій та громад України, Сврейська конфедерація України опікуються питанням протидії расистських та ксенофобських проявів та систематично співпрацюють 3 владою.

Не менш активною $є$ польська громада, що має 120 громадських організацій, серед яких Спілка поляків України та Федерація польських організацій України, які сприяють вивченню і популяризації польської мови, ініціюють відкриття польських шкіл, проводять різноманітні заходи, такі як Дні польської культури, семінари, тренінги, польсько-українські літературні зустрічі, художні та мистецькі виставки.
Німецька громада на чолі $з$ такими організаціями як Рада німців України та Центр німецької культури (загалом 85 організацій) реалізує здебільшого культурні проекти 3 відродження пам'яті відомих німецьких архітекторів, композиторів, меценатів минулого тощо.

Болгарська та вірменська громади мають понад 30 власних організацій різного спрямування, корейська, грузинська, румунська, азербайджанська - понад 10 організацій. Отже, кожна громада національної меншини вирішує для себе, наскільки необхідно їй організовуватися в окремі спільноти і з якою метою, перешкод для цього жодних не створюється, все залежить лише від бажання та настанов тієї чи іншої громади і мети, яку вони прагнуть реалізувати.

Питання фінансування міжнародних і всеукраїнських культурно-просвітницьких заходів також потребує окремої уваги. Кошти, виділені з держбюджету, наприклад, Міністерству культури України, розподіляються власне міністерством, і прозорість цього розподілу можна спостерігати лише останнім часом.

Розглянемо на прикладі харківської територіальної громади, яким чином політика мовної рівності та захисту прав національних меншин впроваджується у м. Харкові. Вся зазначена нижче інформація розташована на офіційному сайті Харківської міської ради, міського голови, виконавчого комітету (Харківська міська рада, 2020).

3 липня 2018 р. у Харківській міській раді працює окремий підрозділ - Відділ по роботі 3 громадськими об'єднаннями, до сфери діяльності якого зокрема входить сприяння стабільності громадських, міжнаціональних та міжконфесійних відносин у місті Харкові, взаємодія з громадськими об'єднаннями в реалізації місцевих програм тощо. Крім того, рік тому у місті Харкові за ініціативою міського голови Геннадія Кернеса була створена Рада національних меншин, до якої ввійшли представники різних національностей.

Крім того, завдяки перевиконанню міського бюджету у I кварталі 2019 р. у квітні того ж року було виділено додатково 5,5 млн грн на закупівлю україномовних дидактичних матеріалів для закладів загальної середньої освіти з навчанням мовами національних меншин.

3 метою підтримки національних меншин у м. Харкові, у Харківській міській раді, 12 грудня 2019 р. відбулася II Міжнародна конференція «Особливості взаємодії органів місцевого самоврядування, іноземних представництв та національних меншин». У заході взяли участь перший 
заступник Харківського міського голови Ігор Терехов, представники департаментів, представники міграційної служби, дипломатичного корпусу, національних меншин і харківських вишів.

Як повідомив перший віцемер, сьогодні в Харкові проживають представники понад 100 національностей, зареєстровані і діють 65 національнокультурних об'єднань, 3 кожним 3 яких міська влада налагодила співпрацю. Він також зазначив, що кожен третій житель міста Харків $є$ представником іншої національності. Міськрада плідно взаємодіє з представниками нацменшин і дипломатичним корпусом, і за весь час у місті ніколи не було ні міжнаціональних, ні релігійних конфліктів. Він наголосив, що міська влада завжди прагнула створити максимально комфортні умови для діяльності всіх національно-культурних товариств. Також I. Терехов зазначив, що в Харкові функціонують два генеральних консульства та 14 консульських установ різних країн.

Розглядаючи ситуацію із загальноосвітніми середніми школами у м. Харкові зауважимо, що на офіційному сайті Харківської міської ради, зокрема у Департаменті освіти, дана інформація відсутня. Питання російськомовних шкіл час від часу обговорюється у харківських ЗМІ, але офіційної інформації щодо принаймні кількості російських шкіл немає. Це зрозуміло, тому що питання дійсно досить незручне: згідно з Законом «Про освіту» та «Про забезпечення функціонування української мови як державної» до 2023 р. в усіх школах має бути впроваджено навчання виключно українською мовою.

У м. Харкові це стосується здебільшого російських шкіл, й останнім часом більшість 3 них перейшла на українську мову навчання, залишивши у навчальному плані такі дисципліни як російська мова та російська література.

Зрештою основна проблема м. Харкова полягає в тому, що більшість населення спілкується на побутовому рівні саме російською мовою, і майже тридцять років незалежності, за які з'явилося не одне покоління, цю ситуацію не змінили майже зовсім. Держустанови та центри надання послуг усіх рівнів на дотримання закону користуються виключно українською мовою, і це добра ознака.

Однак цього не досить. На державному рівні має працювати не лише закон, що передбачає покарання за послуговування недержавною мовою у формі штрафів. На виконання і дотримання цього закону має бути впроваджена довгострокова національна програма, яка б функціонувала за будь-якого уряду, незмінна й стратегічно виважена, завдяки якій державна мова стала б дійсно престижною.

Висновки. Отже, незважаючи на те, що Закон «Про забезпечення функціонування української мови як державної» певним чином обмежує можливості громадян щодо використання мов національних меншин на державному рівні (в держустановах), Закон не обмежує права на вивчення рідної мови тієї чи іншої національності. Те, що єдиною державною (офіційною) мовою в Україні $\epsilon$ українська мова, $є$ невіддільним елементом конституційного ладу України як унітарної держави. Національне законодавство і практика регулювання етнонаціональних процесів у сфері освіти формується Україною відповідно до міжнародних норм і рекомендацій. Але лише державна програма зі створення позитивного іміджу української мови серед населення сприятиме як дотриманню законодавчо-правової бази, так і нівелюванню спекуляцій довкола мовного питання взагалі. У такій програмі мали б окреме місце посідати національні меншини й іноземні громадяни, для яких мали б бути створені окремі умови для вивчення державної мови. Перспектива подальшого дослідження вбачається у вивченні етнічного складу окремих громад і їх нагальних потреб, задоволення яких стане запорукою успішної реалізації мовної політики України.

\section{СПИСОК ВИКОРИСТАНИХ ДЖЕРЕЛ}

1. Андріяш В. І. Державна етнополітика України в умовах глобалізації : монографія. Миколаїв : Вид-во ЧдУ ім. Петра Могили, 2013. 328 с.

2. Закон України «Про забезпечення функціонування української мови як державної» від 25 квітня 2019 р. № 2704-VII. URL: https://zakon.rada.gov.ua/laws/main/2704-19 (дата звернення: 10.06.2020).

3. Закон України «Про засади державної мовної політики» від 3 липня 2012 р. № 5029-VI. URL: https://zakon.rada.gov.ua/laws/show/5029-17 (дата звернення: 10.06.2020).

4. Закон України «Про національні меншини» від 25 червня 1992 p. № 2494-XII. URL: https://zakon.rada.gov.ua/ laws/show/2494-12 (дата звернення: 10.06.2020).

5. Закон України «Про освіту» від 5 вересня 2017 p. № 2145-VIII. URL: https://zakon.rada.gov.ua/laws/ show/2145-19 (дата звернення: 10.06.2020).

6. Кононенко П. П. Етапи розвитку й самопізнання українського народу. Збірник наукових пращь Науково-дослідного інституту українознавства. Київ : Українське агентство інформації та друку «Рада», 2008. T. XXII. С. 281-288.

7. Конституція України (останнє оновлення 03.09.2019р.). URL: https://zakon.rada.gov.ua/laws/show/254\%D0\% BA/96-\%D0\%B2\%D1\%80 (дата звернення: 10.06.2020). 
8. Куртсеітов Р. Д. Вплив системи освіти на процес мовної соціалізації дітей дошкільного та шкільного віку (кримських татар і національних меншин) в умовах сучасного Криму. Вісник Львівського університету. Серія соиіологічна. 2012. Вип. 6. С. 62-72.

9. Міністерство культури та інформаційної політики України. Офіційний сайт. URL: https://mkip.gov.ua/ (дата звернення: 10.06.2020).

10. Міністерство культури України. Офіційний сайт. URL: http://195.78.68.75/mcu/control/uk/publish/ officialcategory?cat_id=35002 (дата звернення: 10.06.2020).

11. Офіційний портал Києва. URL: https://kyivcity.gov.ua/ (дата звернення: 10.06.2020).

12. Офіційний сайт Харківської міської ради, міського голови, виконавчого комітету. URL: https://www.city.kharkov.ua/uk/ (дата звернення: 10.06.2020).

13. Підбережник Н. П. Виклики та загрози у сфері етнополітичних відносин в Україні на сучасному етапі. Вісник НАДУ при Президентові України. Державне управління. 2018. № 2. С. 68-75.

14. Про кількість та склад населення України за підсумками Всеукраїнського перепису населення 2001 року. URL: http://2001.ukrcensus.gov.ua/results/general/nationality/ (дата звернення: 10.06.2020).

15. Рішення Конституційного Суду України у справі за конституційним поданням 57 народних депутатів України щодо відповідності Конституції України (конституційності) Закону України «Про засади державної мовної політики» від 28 лютого 2018 p. № 2-p/2018. URL: https://zakon.rada.gov.ua/laws/show/v002p710-18\#n55 (дата звернення: 10.06.2020).

16. Рішення Конституційного Суду України у справі за конституційним поданням 48 народних депутатів України щодо відповідності Конституції України (конституційності) Закону України «Про освіту» від 16 липня 2019 р. № 10-p/2019. URL: https://zakon.rada.gov.ua/laws/show/v010p710-19\#n2 (дата звернення: 10.06.2020).

17. Юровська Г. О. Проблемні питання захисту прав внутрішньо переміщених осіб. Юридичний радник : електрон. вид. 2017. № 1 (91). URL: http://yurradnik.com.ua/wp-content/uploads/2017/03/Zdebskiy-SHapovalova_YUrovska. pdf (дата звернення: 10.06.2020).

18. Яковлева О. В. Багатомовність як тренд суспільного розвитку та чинник модернізації освіти. Вісник Харківського наиіонального педагогічного ун-ту ім. Г. С. Сковороди. 2016. Вип. 47 (2). С. 93-105.

19. Янковська Г. В. Державна та/або офіційна мови: ототожнення чи розмежування? Науковий вісник Ужгородського національного університету. 2014. Вип. 29(1). С. 123-126.

\section{REFERENCES}

1. Andriyash V. I. (2013) Derzhavna etnopolityka Ukrayiny v umovax globalizatsiyi [State ethnopolitics of Ukraine in the conditions of globalization]. Mykolayiv : Publishing and printing centre of Petro Mohyla ChSU, 328 p. [in Ukrainian].

2. Zakon Ukrayiny "Pro zabezpechennya funkcionuvannya ukrayinskoyi movy yak derzhavnoyi", 25.04.2019, \#2704-VII (2019) [Law of Ukraine "On ensuring the functioning of the Ukrainian language as the state language", 25.04.2019, \# 2704-VII]. URL: https://zakon.rada.gov.ua/laws/main/2704-19 [in Ukrainian].

3. Zakon Ukrayiny "Pro zasady derzhavnoyi movnoyi polityky", 03.07.2012, \# 5029-VI (2012) [Law of Ukraine “On the principles of state language policy”, 03.07.2012, № 5029-VI]. URL: https://zakon.rada.gov.ua/laws/show/5029-17 [in Ukrainian].

4. Zakon Ukrayiny "Pro natsionalni menshyny", 25.06.1992, \# 2494-XII (1992) [Law of Ukraine "On national minorities", 25.06.1992, \# 2494-XII.]. URL: https://zakon.rada.gov.ua/laws/show/2494-12 [in Ukrainian].

5. Zakon Ukrayiny "Pro osvitu", 05.09.2017, \# 2145-VIII (2017) [Law of Ukraine "On education", 05.09.2017, \# 2145-VIII]. URL: https://zakon.rada.gov.ua/laws/show/2145-19 [in Ukrainian].

6. Kononenko P. P. (2008) Etapy rozvytku y samopiznannya ukrayinskogo narodu [Stages of development and selfknowledge of the Ukrainian people]. Scientific Journal of the Research Institute of Ukrainian Studies. Kyiv : Ukrainian agency of information and publishing "Rada". V.XXII. P. 281-288. [in Ukrainian].

7. Konstytutsiya Ukrayiny (ostannye onovlennya 03.09.2019) (2019) [Constitution of Ukraine (last updated on September 3, 2019)]. URL: https://zakon.rada.gov.ua/laws/show/254\%D0\%BA/96-\%D0\%B2\%D1\%80 [in Ukrainian].

8. Kurtseitov R. D. (2012) Vplyv systemy osvity na proces movnoyi sotsializatsiyi ditey doshkilnogo ta shkilnogo viku (krymskyh tatar i natsionalnyh menshyn) $\mathrm{v}$ umovax suchasnogo Krymu [The influence of the education system on the process of language socialization of preschool and school age children (Crimean Tatars and national minorities) in the conditions of modern Crimea]. Scientific Journal of L’viv National University. № 6. P. 62-72. [in Ukrainian].

9. Ministerstvo kultury ta informatsiynoyi polityky Ukrayiny. Ofitsiynyi sayt (2020) [Ministry of Culture and Information Policy of Ukraine. Official site]. URL: https://mkip.gov.ua [in Ukrainian].

10. Ministerstvo kultury Ukrayiny. Ofitsiynyi sayt (2020) [Ministry of Culture of Ukraine. Official site]. URL: http://195.78.68.75/mcu/control/uk/publish/officialcategory?cat_id=35002 [in Ukrainian].

11. Ofitsiynyi portal Kyyeva (2020) [Official portal of Kyiv]. URL: https://kyivcity.gov.ua/ [in Ukrainian].

12. Ofitsiynyi sayt Kharkivskoyi miskoyi rady, miskogo golovy, vykonavchogo komitetu (2020) [Official site of Kharkiv city council, mayor, executive committee]. URL: https://www.city.kharkov.ua/uk/ [in Ukrainian].

13. Pidberezhnyk N. P. (2018) Vyklyky ta zagrozy u sferi etnopolitychnyh vidnosyn v Ukrayini na suchasnomu etapi [Challenges and threats in the field of ethnopolitical relations in Ukraine at the present stage]. Scientific Journal of NASA. № 2. P. 68-75. [in Ukrainian].

14. Pro kilkist ta sklad naselennya Ukrayiny za pidsumkamy Vseukrayinskogo perepysu naselennya 2001 roku (2001) [On the number and composition of the population of Ukraine according to the results of the All-Ukrainian census of 2001]. URL: http://2001.ukrcensus.gov.ua/results/general/nationality/ [in Ukrainian]. 
15. Rishennya Konstytutsiynogo sudu Ukrayiny u spravi za konstytutsiynym podannyam 57 narodnyh deputativ Ukrayiny shchodo vidpovidnosti Konstytutsiyi Ukrayiny (konstytutsiynosti) Zakonu Ukrayiny "Pro zasady derzhavnoyi movnoyi polityky" vid 28.02.2018, \#2-r/2018 (2018) [Decision of the Constitutional Court of Ukraine in the case on the constitutional petition of 57 people's deputies of Ukraine on compliance with the Constitution of Ukraine (constitutionality) of the Law of Ukraine “On Principles of State Language Policy”, 28.02.2018, № 2-r / 2018]. URL: https://zakon.rada.gov.ua/ laws/show/v002p710-18\#n55 [in Ukrainian].

16. Rishennya Konstytutsiynogo sudu Ukrayiny u spravi za konstytutsiynym podannyam 48 narodnyh deputativ Ukrayiny shchodo vidpovidnosti Konstytutsiyi Ukrayiny (konstytutsijnosti) Zakonu Ukrayiny "Pro osvitu" vid 16.07.2019, \# 10-r/2019 (2019) [Decision of the Constitutional Court of Ukraine in the case on the constitutional petition of 48 people's deputies of Ukraine on the compliance of the Constitution of Ukraine (constitutionality) of the Law of Ukraine "On Education", 16.07.2019, \# 10-r/2019]. URL: https://zakon.rada.gov.ua/laws/show/v010p710-19\#n2 [in Ukrainian].

17. Yurovska G. O. (2017) Problemni pytannya zahystu prav vnutrishno peremishchenyh osib [Problematic issues of protection of the rights of internally displaced persons]. Law Adviser : e-issue. \#1(91). URL: http://yurradnik.com.ua/ wp-content/uploads/2017/03/Zdebskiy-SHapovalova_YUrovska.pdf [in Ukrainian].

18. Yakovleva O. V. (2016) Bagatomovnist yak trend suspilnogo rozvytku ta chynnyk modernizatsiyi osvity [Multilingualism as a trend of social development and a factor in the modernization of education]. Scientific Journal of Skovoroda Kharkiv national pedagogical university. \#72 (2). P. 93-105. [in Ukrainian].

19. Yankovska G. V. (2014) Derzhavna ta/abo ofitsiyna movy: ototozhnennya chy rozmezhuvannya? [State and / or official languages: identification or differentiation?] Scientific Journal of Uzhgorod National University. \#29 (1). P. $123-126$. [in Ukrainian]. 